\title{
"Problems and forecast of the development of the Russian fuel and energy complex: the factorial approach"
}

$\begin{array}{ll}\text { AUTHORS } & \begin{array}{l}\text { Irina A. Toimentseva } \\ \text { Natalia P. Karpova } \\ \text { Natalia G. Ostroukhova } \\ \text { Vera D. Chichkina }\end{array} \\ \text { Irina A. Toimentseva, Natalia P. Karpova, Natalia G. Ostroukhova and Vera D. } \\ \text { Chichkina (2017). Problems and forecast of the development of the Russian fuel } \\ \text { and energy complex: the factorial approach. Problems and Perspectives in } \\ \text { Management, 15(2-2), 372-385. doi:10.21511/ppm.15(2-2).2017.07 }\end{array}$

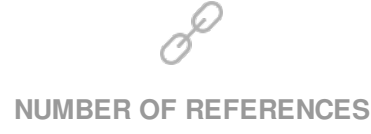

38
NUMBER OF FIGURES

4
靖

NUMBER OF TABLES

3

(C) The author(s) 2023. This publication is an open access article. 


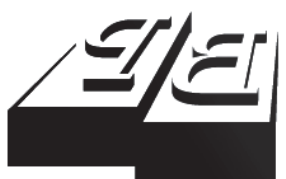

BUSINESS PERSPECTIVES

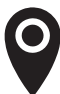

LLC "CPC "Business Perspectives" Hryhorii Skovoroda lane, 10, Sumy, 40022, Ukraine

www.businessperspectives.org

Received on: $30^{\text {th }}$ of March, 2017

Accepted on: $3^{\text {th }}$ of July, 2017

(C) Irina A. Toimentseva (Russia), Natalia P. Karpova (Russia), Natalia G. Ostroukhova (Russia), Vera D.

Chichkina (Russia)

Irina A. Toimentseva, Doctor of Economics, Professor of Department of Marketing, Logistics and

Advertising, Samara State University of Economics, Russia.

Natalia P. Karpova, Doctor of Economics, Professor of Department of Marketing, Logistics and Advertising, Samara State University of Economics, Russia.

Natalia G. Ostroukhova, Candidate of Economics, Associate Professor, Department of Economics, Syzran Branch of Samara State Technical University, Russia.

Vera D. Chichkina, Candidate of Economics, Head of Department of Economics, Syzran Branch of Samara State Technical University, Russia

\section{(ㄷ)(1) $(9$}

This is an Open Access article, distributed under the terms of the Creative Commons Attribution-NonCommercial 4.0 International license, which permits re-use, distribution, and reproduction, provided the materials aren't used for commercial purposes and the original work is properly cited.
Irina A. Toimentseva (Russia), Natalia P. Karpova (Russia),

Natalia G. Ostroukhova (Russia), Vera D. Chichkina (Russia)

\section{PROBLEMS AND FORECAST} OF THE DEVELOPMENT

OF THE RUSSIAN FUEL AND ENERGY COMPLEX: THE FACTORIAL APPROACH

\begin{abstract}
Existing forecasts of Russian energy sector development have a number of general provisions and differ in approaches to their construction. The most realistic forecast is made within the framework of the Energy Strategy of Russia for the period up to 2035. However, the dynamism and high uncertainty of economic processes, international relations, domestic policy and the rapid growth of scientific and technical progress need a systematic correction of any forecast. The purpose of the article is to develop theoretical provisions and practical recommendations for making a forecast for the development of the Russian fuel and energy complex based on the application of the factor approach.

The forecasting results are used in the development of management decisions, therefore, the authors of the article take into account the influence of various factors while making the forecast, but they (factors) are all quantitatively commensurable. To make a reliable forecast, the internal environment of the research object is studied in detail, organizational and economic problems in the development of the Russian fuel and energy complex are revealed, and methods for their elimination are suggested. The external environment is also analyzed and trends in the development of world energy markets are revealed. To forecast the state of the fuel and energy complex, an integral indicator is chosen reflecting the level of its technical and economic development.
\end{abstract}

\section{Keywords}

Russia’s energy strategy, energy intensity of GDP, innovative activity, development factors, technological structure, technical and economic problems

\section{JEL Classification L71, O33, E37}

\section{INTRODUCTION}

The types of economic activity associated with the production and transformation of fuel and energy resources into various types of energy and energy carriers have always had a special significance for the national economy of Russia. In the second half of the XIX century due to significant and available reserves of coal and oil, the country had an optimal structure of the fuel and energy balance. The establishment and development of all branches of the national economic complex in the Soviet Union, the fulfillment of plans for a five-year economic development would not have been possible without the availability of its own energy resources in sufficient quantities. The transition to a market economy in the 1990s, the restructuring of the social and political system in the country increased budget expenditures manifold, which were recovered by revenues from energy exports. 


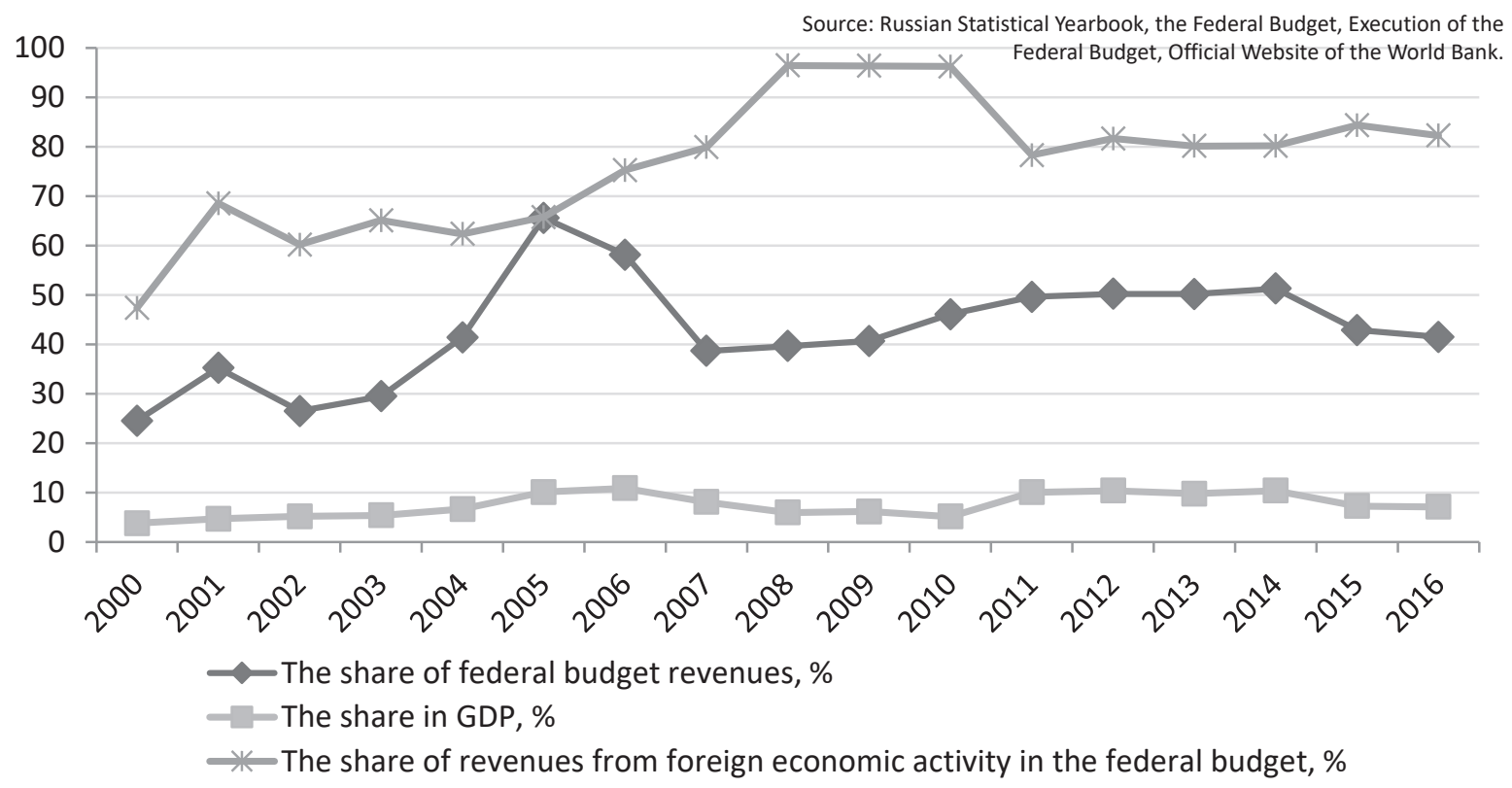

Figure 1. Macroeconomic indicators of the fuel and energy complex of Russia in 2000-2016

Thus, throughout its existence, the fuel and energy complex (FEC) of Russia is the main strategic security, independence and economic development of the country. On the one hand, this is due to geographic and climatic factors and significant hydrocarbon reserves on the territory of the state; on the other hand, it is due to realizable foreign and domestic policies.

At present, the fuel and energy sector occupies a leading position in the formation of the revenue side of the federal budget (Figure 1).

The graph reflects changes in macroeconomic indicators of the complex during the 2008 global economic crisis, economic sanctions of 2014, and the global economic slowdown that has been observed for the last three years. The economic decline at the global or national level, caused by various reasons, always leads to a reduction in energy consumption. The dynamics of exports of fuel and energy products, in addition, is determined by foreign policy.

The above schedule also reflects the existing model of the national economy - raw materials. This can be seen from the ratio of the share of the fuel and energy sector to GDP and its contribution to federal budget revenues. During the analyzed period, the difference between these indicators almost doubled. This is also a negative characteristic of the use of energy resources.

Thus, there is a direct relationship between the quantity and efficiency of energy consumption and economic growth. This fact, as well as the raw material model of the Russian economy, makes it necessary to study trends and build forecasts for the development of the country's fuel and energy complex.

\section{LITERATURE REVIEW}

The work of V. V. Bushuev (2014) provides a forecast for the development of the economy and energy based on structural principles and spatiotemporal fractals. In the near future, the economy of developed countries will be presented as neoindustrial, based on energy-information technol- ogies. Currently, there is a formation of regional (international) "infrastructure development corridors", which include both physical objects (power lines, gas and oil pipelines), and institutions (generally accepted rules, standards for the movement of energy resources). The authors predict an increase in the energy self-sufficiency of importing states and a reduction in the struggle intensity for 
hydrocarbon energy resources. As a result, the direction of international energy flows will change significantly and competition between energy exporting countries will increase. In these conditions, revenues from energy exports will decrease. The authors note that there will be significant changes in energy consumption: the role of electricity will increase, but the role of fuel will decrease.

A. A. Galkina et al. (2011) in their study predict the diversification and balance of energy consumption on a global scale. According to their calculations, the leading energy carrier will be natural gas, the share of renewable energy sources will increase. Against the background of the growing self-sufficiency in unconventional energy resources of importing countries, there will be a change in trade flows of energy resources on a global scale. The development of regional and global markets for energy resources, according to the authors' forecast, will be affected by scientific developments. The ongoing changes in the world energy industry will lead to a decrease in the income from the export of energy resources for Russia.

A. A. Makarov, T. A. Mitrova and V. A. Kulagin (2012) also forecast an increase in the self-sufficiency of the United States and a number of importers with unconventional energy resources. The planned increase in energy consumption will be covered by inorganic energy resources. Under these conditions, the revenues from the export of energy resources to the Russian budget will decrease, the share of the fuel and energy complex in the formation of GDP will triple, and the complex will lose its role as a locomotive of the national economy so a geopolitical tool.

Ja. M. Mirkin (2014) in his work forecasts possible options for the development of the Russian economy with reference to the dynamics of world oil prices: a reduction in the supply of energy resources to Europe and a growth in sales in Asian markets, a fall in energy prices and, as a result, a decrease in export earnings, problems with transport infrastructure - a high degree of depreciation and a lack of funds to create a new one.

Jean-Francois Mercure and Pablo Salas (2013), creating a model for the forecast of energy prices, note the factors that have the most significant im- pact on energy, such as environmental and scientific and technical. The authors pay special attention to how technologies in energy industries will spread, and what changes they will entail.

Dirk Jan van de Ven and Roger Fouquet (2017) study the impact of a shift in leading energy resources on the cyclical nature of the economy. The authors predict the optimization of energy consumption by increasing the share of renewable energy sources. Researchers point out that the previous experience of the negative influence of the price dynamics of energy resources on the economy contributes to the search for ways to reduce dependence on hydrocarbons.

In general, all these forecasts and a number of other ones for the development of the world energy and economy are based on geopolitical and scientific and technical factors.

\subsection{Establishing a research gap}

The forecasts for the development of the global energy and economy have been compiled taking into account key factors, mainly foreign policy and are presented in scientific papers mentioned in the literature review.

For energy markets, the direction of commodity flows is currently characterized: from the US and EU markets to APR markets. This is facilitated by changing relations between exporting countries and importers, as well as the growing role of the environmental component in energy consumption. A number of man-made disasters (explosion on the Deepwater Horizon platform in 2010, accidents at the Fukushima-1 nuclear power plant, gas leakage on the Elgin platform in 2012) reduced the popularity of nuclear energy and hydrocarbon fuel in developed countries.

In conditions of economic instability, many states are changing their tax, customs and environmental legislation to protect their national interests. This, in turn, depending on the situation, can have both a favorable and negative impact on the world trade in energy resources.

Priority energy problems (environmental friendliness, energy intensity of GDP, limited energy re- 
sources, energy dependence of importing countries) are being successfully addressed through the development of science and technology. The influence of the scientific and technological progress is changing the demand for energy carriers and it happens, first of all, due to new types of economic activity. The change in demand eventually changes the conjuncture of global energy markets (Lin Zheng-Wei, Hsu Sam TingHsin, \& Huang Chin-Sheng, 2014; Postaliuk \& Kwon, 2014).

The introduction of information technology contributes to the globalization of global energy markets and the integration of regional ones (a gas market in the EU).

Crisis phenomena in the world economy create prerequisites for reforming world energy markets in general and energy markets of participating countries. The main direction of reforms is liberalization and creation of conditions for fair competition.

The decline in demand in world energy markets, caused by the general economic slowdown, is exacerbated by political factors - exacerbation of earlier ones and the emergence of new conflicts (Syria, Ukraine, etc.) (Tsakalos Ioannis, Samitas Aristeidis, \& Kinias Ioannis, 2015).

The above-listed problems and trends in the development of world energy markets significantly reduced the competitive advantage of Russia.

The instability of world energy markets, the presence of a large number of globalization threats of the world energy, the reorientation from European markets to the markets of the Asia-Pacific region, long-term relations with China (Bildirici Melike, 2016) require the development of an effective strategy of domestic energy companies in the world arena to strengthen their capabilities, to strengthen weaknesses and quickly solve emerging problems.

The authors of this article believe that structural factors determining the composition, the performance and organizational and economic state of the Russian fuel and energy sector are also important for forecasts.

\subsection{Aim of the study}

The purpose of the study is to identify the factors that determine the functioning of the fuel and energy complex in Russia and make a forecast of its development based on the regression analysis.

To achieve this goal, the following tasks have been solved in the course of research:

- the existing forecasts of the development of the fuel and energy complex of Russia have been studied;

- in the foreseen forecasts, the factors determining the state and development of the domestic fuel and energy complex have been identified;

- based on the conducted regression analysis, accounting for the Energy Strategy of Russia and the dynamics of the key factor (innovative activity), the forecast has been made for the development of the fuel and energy complex of Russia until 2035-2040.

The object of this research are enterprises of the fuel and energy complex of Russia, the subject of research is the ways of developing economic relations between enterprises of the fuel and energy complex.

\section{METHODOLOGICAL FRAMEWORK}

\subsection{Methods of research}

In the course of this research, the following methods were used: collection and processing of statistical information, method of graphic images, regression analysis and factor approach.

\subsection{Experimental research base}

The experimental base of this research has been made by enterprises of the fuel and energy complex of Russia: PJSC "Gazprom", PJSC "NK Rosneft", State Corporation "Rosatom", PJSC "RusHydro", "NP Market Council". 


\subsection{Stages of research}

The authors of the article have carried out a comprehensive analysis of the formation and development of industries of the fuel and energy sector of Russia and assessed its current state. Based on the results of the study, the factors determining the development of the complex have been identified and evaluated (Table 1).

Table 1. Factors determining the development of the fuel and energy complex of Russia

Source: Bushuev et al. (2012). History of the Russian energy sector, Glaz'ev (2007), M. G. Lapaeva and O. F. Lapaeva (2004).

\begin{tabular}{l|c:c}
\hline \multicolumn{1}{c}{ Factor } & $\begin{array}{c}\text { Possibility } \\
\text { of influence }\end{array}$ & $\begin{array}{c}\text { Possibility } \\
\text { of forecasting }\end{array}$ \\
\hline $\begin{array}{l}\text { The state of sectoral } \\
\text { industrial markets }\end{array}$ & + & + \\
\hdashline $\begin{array}{l}\text { Domestic policy } \\
\text { of the state }\end{array}$ & - & - \\
\hdashline $\begin{array}{l}\text { Macroeconomic } \\
\text { indicators }\end{array}$ & - & + \\
\hline $\begin{array}{l}\text { Foreign policy } \\
\text { of the state }\end{array}$ & + & + \\
\hline $\begin{array}{l}\text { Technical and economic } \\
\text { problems }\end{array}$ & & + \\
\hline $\begin{array}{l}\text { The state of the world } \\
\text { economy and world } \\
\text { energy markets }\end{array}$ & - & + \\
\hline $\begin{array}{l}\text { Personal interests } \\
\text { of owners of energy } \\
\text { companies' assets, } \\
\text { officials }\end{array}$ & & \\
\hline
\end{tabular}

Two criteria have been chosen to assess the factors:

1. The possibility of forecasting is necessary to assess the contribution of each factor to the state of the fuel and energy complex.

2. The possibility of influence will allow to make the forecast.

3. Based on the assessment, the results of which are presented in Table 1, the authors have compiled a matrix of factors to make a forecast for the development of the fuel and energy complex (Figure 2).

Taking into account the above mentioned signs, we will choose factors from the right upper sector to forecast the development of the fuel and energy complex of Russia - the state of complex's industrial markets and technical and economic problems. Let us consider the essence and peculiarities of accounting for these factors in forecasting.

One of the structural factors determining the development of the fuel and energy sector is the model of industrial markets. At present, a number of programs for reforming the complex's industries are being implemented, aimed at creating markets in them which are close to perfect (Ostrouhova, 2015b).

\section{The possibility} of influence
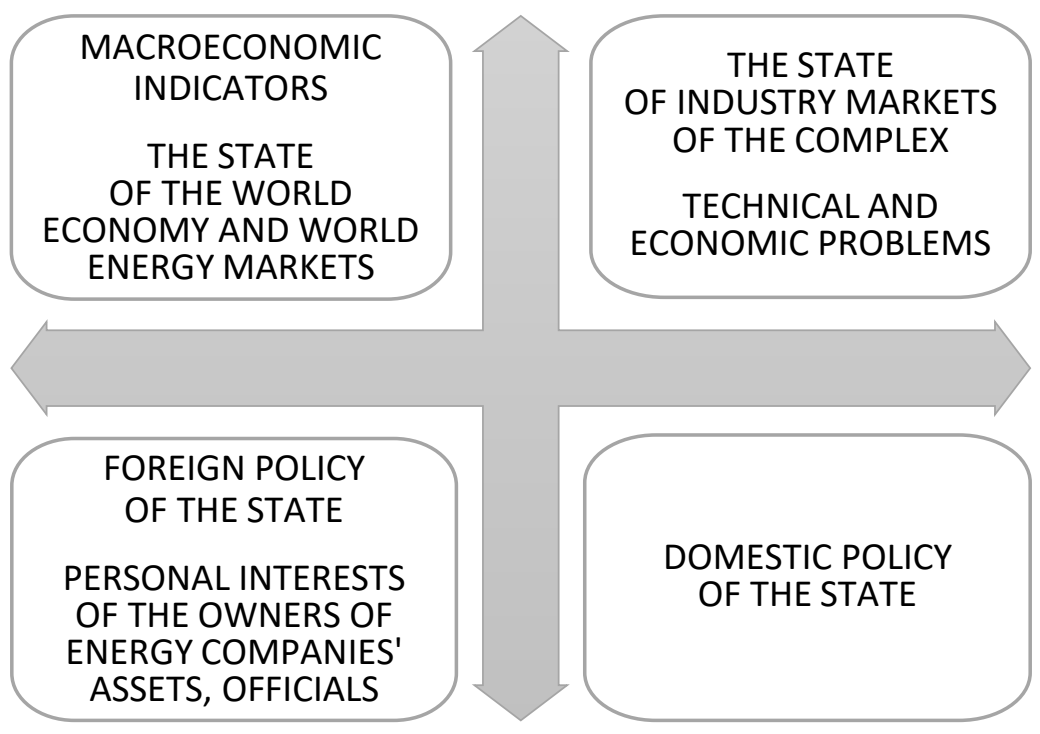

The possibility of forecasting

Figure 2. Matrix of factors for forecasting the development of the fuel and energy sector 
Source: Report and presentation to the speech of the Deputy Minister Alexey Teksler on the forum of the fuel and energy complex of Russia in the XXI century, Russian statistical yearbook.

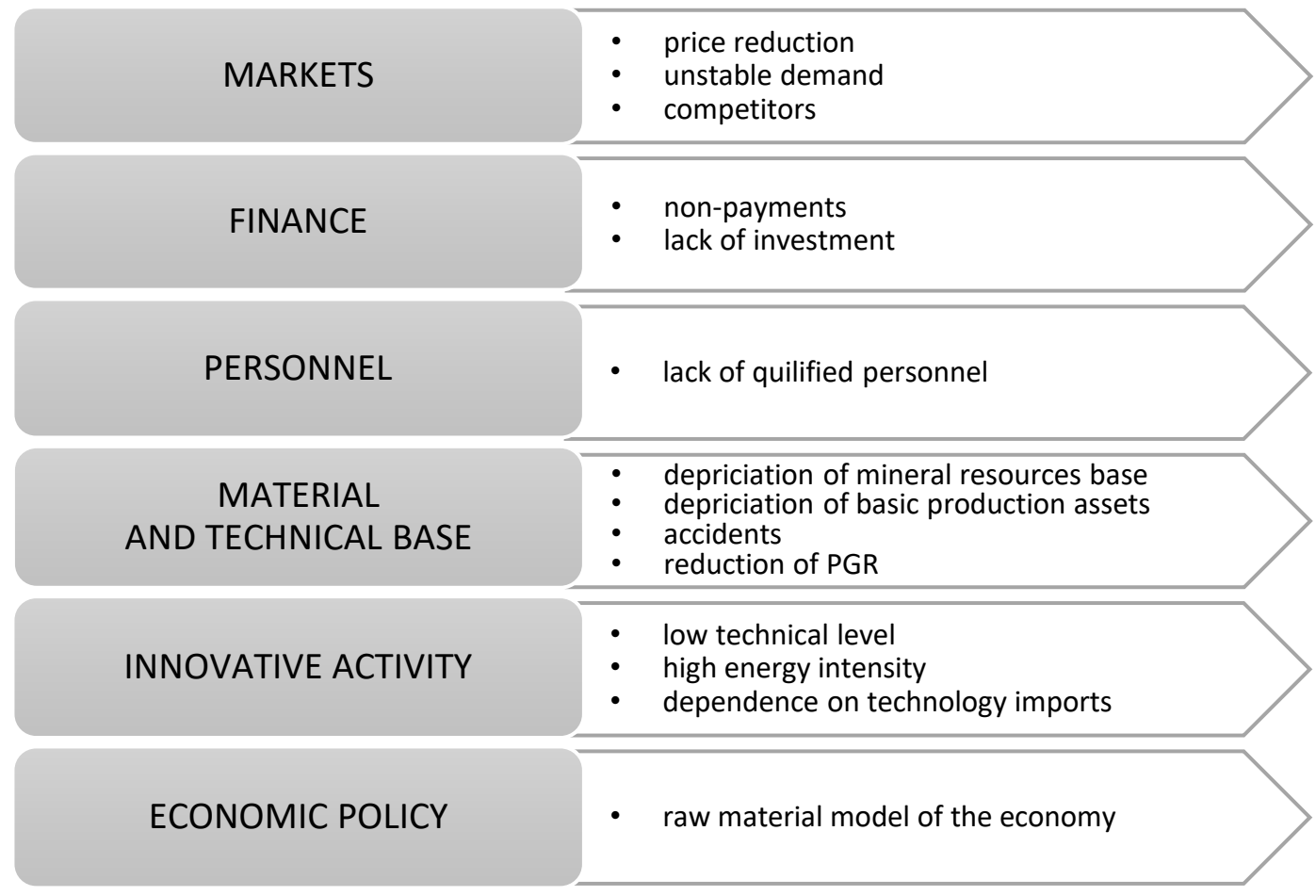

Figure 3. Performance issues of the fuel and energy complex of Russia

Another internal factor that determines the prospects for the development of the fuel and energy sector of Russia is the existing organizational, economic and technical issues that are discussed in detail in the work of N. G. Ostrouhova (2015a). The issues of the fuel and energy complex of Russia are presented schematically in Figure 3.

Thus, in the forecasts of the development of the fuel and energy complex of Russia, taking into account this factor, various ways of eliminating the above mentioned issues appear. One of the most effective and corresponding to modern economic conditions is the implementation of innovation.

The implementation of innovative activities will also solve one of the key issues of both the domestic energy complex and economy as a whole - a high energy intensity of GDP. The energy intensity of Russia's GDP is 0.74 , in the USA it is 0.15 , in Germany - 0.1, and in Britain - 0.07.

The correlation analysis of the energy intensity of GDP and the share of R \& D expenditures in GDP has showed the presence of a reverse close dependence between these parameters, which is reflected in Figure 4. The correlation coefficient was -0.58 . With the increase in $R \& D$ spending, the energy intensity of GDP is declining.

The development of the fuel and energy complex of Russia and the economy as a whole is reflected in the works of V. V. Ivanter and V. S. Panfilov (2011), V. Gorshenin (2010), Ju. V. Trifonov and L. N. Letjagina (2010). These works and a number of others are fragments of the scientific direction devoted to the cyclical nature of the economic development. The most relevant and in demand are the works of S. Ju. Glaz'ev (2007, 2010), Glaz'ev, and Kharitonov (2009) on the development of economic systems within technological structures.

The fuel and energy complex is a subsystem of the complex socio-economic system - national economy. And at the same time it is a technical and economic system. Thus, the complex goes through development stages similar to complex economic systems and is affected by the same factors. Consequently, the forecast for the development of the fuel and energy complex of Russia should be 
Source: Key World Energy Statistics (2016), The Global Innovation Index (2016).

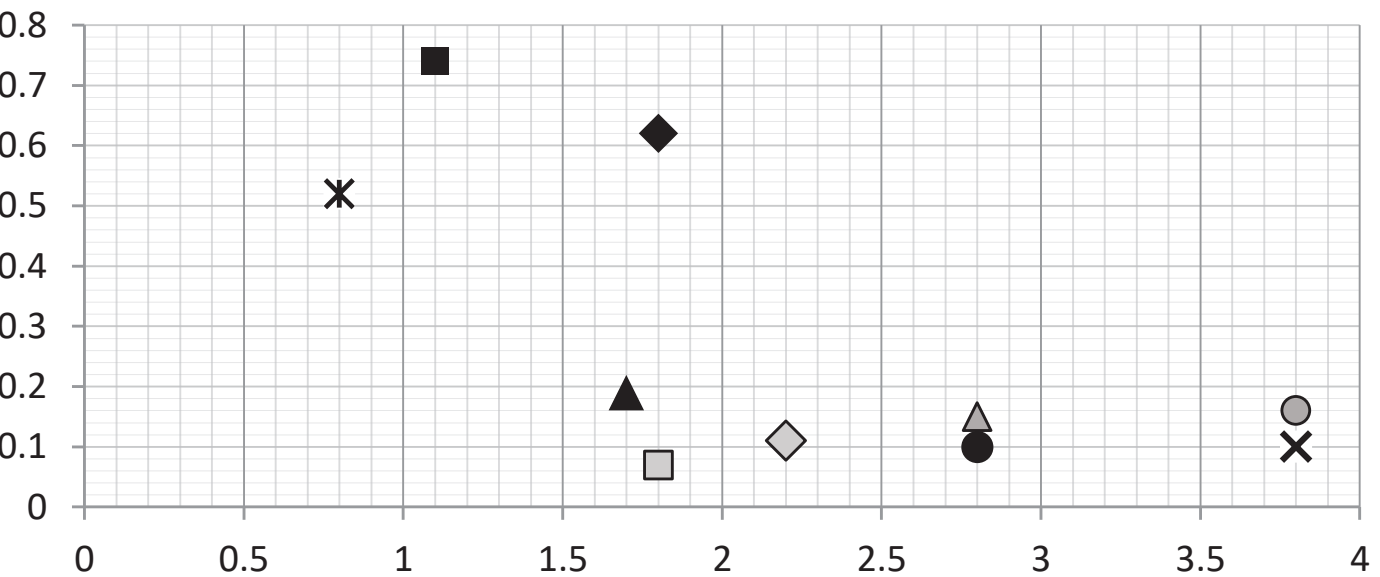

The share of R\&D expenditures in GDP, \%

\begin{tabular}{|c|c|c|c|}
\hline China & * Indian & - Canada & OFinland \\
\hline$\diamond$ France & XJapan & 口UK & - German \\
\hline
\end{tabular}

Figure 4. The correlation share of R\&D expenditures in GDP and the energy intensity of GDP in different countries

drawn up taking into account scientific and technological progress and the approaching shift in technological structures.

The Russian economy of the late twentieth and early twenty-first centuries can be characterized as multistructural: more than half of all branches in the national economy are the leading branches of the IV technological order, about a third - the branches of the third technological order. The share of the fifth, completing in all developed countries, technological structure accounts for no more than $10 \%$ of the branches of the Russian economy.

The present (fifth) technological structure according to experts' estimates is close to the limits of its growth, as evidenced by a spasmodic change in energy prices in 2014-2016.

Crisis phenomena in the world economy and a number of national economies, social upheavals (armed conflicts in Syria and Ukraine), natural disasters, technogenic catastrophes (accidents at the Sayano-Shushenskaya HPP, Fukushima-1 NPP) also indicate a change in technological structures. These phenomena correspond to the downward wave of N. V. Kondratiev cycle. The economic de- cline, if we trace back to the history of the economy, is the time to accumulate the potential for the beginning of the next cycle, the next wave, the next technological order. Toward the end of the depression stage, the tendency to invest in fixed assets increases, as a result of which it is being updated and radical innovations are implemented.

The branches of the upcoming sixth technological order (nanotechnology, biotechnology and cognitive technologies, etc.) are not developed in Russia. The reasons for this lie in the history of the energy development (Gorshenin, 2010; Ivanter \& Panfilov, 2011; M. G. Lapaeva \& O. F. Lapaeva, 2004; Rybcev, 2011; Trifonov \& Letjagina, 2010).

The guidelines for the strategic development of the fuel and energy complex within the framework of Energy Strategy of Russia for the period up to 2035 (Report and presentation to the speech of Deputy Minister Alexei Texler at the forum of the fuel and energy complex of Russia in the 21st century, 2014) should be implemented in the process of transition to the VI technological order that will have taken place by 2018 (Gorshenin, 2010). The nucleus of the new technological order will be nanotechnology, biotechnology and cognitive technologies (Rybtsev, 2011). 
In transitional years 2015-2018, Russia needs to use all available resources and innovation potential for restructuring the domestic economy to a new technological order. The lost opportunities during the redistribution of political and economic positions in the world will create a threat to national security.

Changes of technological wave will demand a significant amount of various production including energy resources. Therefore the role of energy industry in the next years will increase in economy not as a main source of the budgetary income but as an auxiliary element of the transition process. To ensure new requirements of changing economy and developing industry the energy industry has to undergo a number of changes. It concerns, first of all, the structure of the fuel and energy balance. According to dialectics of the energy structure, electric energy should replace oil and gas and has to occupy the largest part in the structure of energy carriers of the country in the nearest future (M. G. Lapaeva \& O. F. Lapaeva, 2004; Bushuev et al., 2012).

The sixth technological wave also assumes the development of new nonhydrocarbonic, environmentally friendly energy sources, further development of energy saving technologies (Ribtsev, 2011). At this time, according to experts' forecasts (Bushuyev et al., 2012; Plakitkin, 2012), there will be the change of structure and reduction of energy consumption volumes on a global scale, at the same time the energy role in production will strengthen (Rybtsev, 2011).

Thus, Russia has an opportunity to go away from a raw economy model. However, to implement this opportunity, it is necessary to use effectively all available resources and innovative capacity of the country. The effective use assumes not only planning and organization of events on economy reorganization, but also management of these events. It means that there will not be only technological, but also management innovations: the development of new approaches to management, modernization of existing ones. Administrative innovations will be required also in newly created branches, and in existing ones, including energy industry.
Management innovations promote an increase in efficiency of enterprises' functioning and correspond to implemented liberalization of energy markets. In general, they create a favorable investment climate in branches of the energy industry. Additional capital investments will allow solving raw, engineering and technological problems of the energy complex.

The increase in demand and prices of oil which was observed in 2007-2008 and other energy carriers testified about the beginning of the replacement process of the outdated technological wave with a new one. The increase in prices for energy carriers during the transition period is caused by their excess consumption in expanded technological chains of the old technological pattern. The expansion in consumption of raw materials and energy remains also in the initial stage of the new technological wave, however, it is already caused by developing new production and it is the share of more effective energy carriers. Thus, demand for energy resources (including Russian) will increase at the expense of leading countries of a new technological paradigm.

In general, during an upward wave of the economic development within the technological paradigm, there will be an increase in prices for energy carriers. The increase in prices for energy carriers which began in 2016 can also be estimated as the indicator of transition to the forth technological pattern. The tendency of the increase in prices will remain in the next 10 years.

According to S. Ju. Glaz'ev's forecasts (2007, 2010), within the forth technological wave space technologies, atomic industry, flexible production automation of constructional materials with the properties which were set in advance, air transportation will intensively develop.

All specified kinds of activity will indirectly or directly lead to the growth in mining of energy resources and generation of energy.

Atomic energy and natural gas as the main energy carriers will be added with environmentally friendly hydrogen, and also renewable energy sources. Economic growth will require smaller amount of energy and materials, therefore, de- 
mand for energy carriers will lag behind the volumes of product output in connection with the use of new energy saving technologies.

According to the analysts' forecasts in a short term perspective (till 2030) the growth in volumes of consumption of fossil energy resources (Maslennikova, 2010; Kipnis, 2014; Demina \& Novickij, 2012) and their decrease in a long-term perspective (Plakiktin, 2012, 2013) will be observed. It is connected in the first case with the population growth of the planet, in the second - with the scientific and technical progress, the transition to the sixth technological pattern in which hydrocarbons will not be the leading energy carrier.

Within the coming change of technological waves and key energy carrier such tendencies of the innovative energy development as renewable energy sources and distributed energy are getting relevant. In view of geographical and climatic conditions for Russia the distributed energy is more important: many areas can't be connected to the integrated energy system and, therefore, they need autonomous energy sources which are heat and power plants that can work with different types of hydrocarbons and different technologies. As generation sources, in this case, a hydroelectric power station and a nuclear power station, aren't suitable because of their technological complexity, they need considerable capital investments and developed infrastructure.

However, the distributed energy won't be as a widespread as traditional one. It is explained by quantity and power of its consumers. The areas which are not covered with the traditional generation companies are not the main centers of energy consumption. The most power-consuming industries connected with production and processing of various minerals, the Ural, West Siberian, East Siberian and Far East districts receive energy from the integrated power system.

\section{RESULTS}

The analysis of the scientific literature, statistical information, and the results of the activity of certain enterprises of the fuel and energy complex, made by the authors of the article, made it possible to single out two main factors determining the development of the complex and available for management based on the results of forecasting:

1) the state of sectoral industrial markets;

2) technical and economic problems.

It is also theoretically justified that the leading role in the development of the fuel and energy complex of Russia belongs to innovation activity.

To make a forecast for the development of the fuel and energy complex of Russia, two main factors have been taken into account: "the state of the complex's industrial markets" and "technical and economic problems", then, the regression model has been made. It is important to take into account the fact that the analyzed feature (the state of the energy sector of Russia) and identified factors should have a quantitative feature for the regression analysis.

The state of the fuel and energy complex and its impact on the national economy reflects such an indicator as the energy intensity of GDP. Its high importance is one of Russia's key energy problems, which indirectly reflects structural and financial problems of the fuel and energy sector. The reduction of this indicator is a positive characteristic of the development of the complex.

For the regression analysis, the indicator "the level of energy intensity of primary energy ( $\mathrm{MJ} / \mathrm{\$}$ in prices of 2001 at purchasing power parity of GDP)" has been used.

The revealed tendencies of liberalization of world energy markets are reflected in domestic energy markets of Russia. Therefore, the quantitative expression of the factor "the state of industrial markets of the complex" is the level of concentration of production in the complex.

The main technical and economic problems of the fuel and energy sector of Russia include a high degree of depreciation of the basic production assets of industries and a low innovation activity (a backlog in the level of the technical development). To carry out a quantitative analysis 
Table 2. Initial data for the regression analysis

Source: Russian Statistical Yearbook (Rossijskij statisticheskij ezhegodnik).

\begin{tabular}{|c|c|c|c|c|c|}
\hline Year & $\begin{array}{l}\text { The level of energy } \\
\text { intensity of primary } \\
\text { energy (MJ / \$ in prices } \\
\text { of } 2001 \text { at purchasing } \\
\text { power parity of GDP) }\end{array}$ & $\begin{array}{l}\text { Depreciation } \\
\text { of basic } \\
\text { production } \\
\text { assets, \% }\end{array}$ & $\begin{array}{c}\text { Share of enterprises } \\
\text { that carried out } \\
\text { technological } \\
\text { innovation, } \%\end{array}$ & $\begin{array}{c}\text { Concentration of } \\
\text { production, } \%\end{array}$ & $\begin{array}{c}\text { Share of } \\
\text { investments, \% }\end{array}$ \\
\hline 2000 & 13.42 & 52.3 & 4.6 & 42.9 & 16.7 \\
\hline 2001 & 12.92 & 46.7 & 4.6 & 38.6 & 17.5 \\
\hline 2002 & 12.27 & 54.8 & 7.6 & 41.7 & 15.5 \\
\hline 2003 & 11.85 & 54.8 & 7.3 & 41.7 & 14.4 \\
\hline 2004 & 11.09 & 54.8 & 6.2 & 38.8 & 14.0 \\
\hline 2005 & 10.49 & 53.3 & 5.7 & 32.1 & 12.4 \\
\hline 2006 & 9.99 & 53.4 & 8.0 & 33.1 & 13.3 \\
\hline 2007 & 9.23 & 50.9 & 6.6 & 37.8 & 12.5 \\
\hline 2008 & 8.97 & 51.1 & 5.6 & 21.5 & 12.2 \\
\hline 2009 & 9.15 & 50.2 & 7.0 & 21.9 & 12.9 \\
\hline 2010 & 9.52 & 51.1 & 8.0 & 23.4 & 12.7 \\
\hline 2011 & 9.58 & 51.4 & 9.9 & 34.3 & 12.6 \\
\hline 2012 & 9.42 & 49.5 & 9.6 & 23.9 & 13.1 \\
\hline 2013 & 9.54 & 50.4 & 9.7 & 23.3 & 13.6 \\
\hline 2014 & 9.39 & 51.6 & 7.8 & 23.7 & 14.6 \\
\hline 2015 & 9.37 & 50.0 & 4.5 & 23.0 & 16.8 \\
\hline
\end{tabular}

of the identified problems of the complex, such indicators as "depreciation of fixed production assets" and "specific weight of organizations that carried out technological innovations" have been used.

The main economic problem of the fuel and energy complex of Russia is the lack of investment. For their quantitative evaluation, the indicator "specific weight in the total volume of investments in fixed assets" has been used.

Data on the listed indicators for 2000-2015 are given in Table 2.

The conducted regression analysis made it possible to compile the following model reflecting the state of the fuel and energy complex of Russia:

$y=0.77-0.03 x_{1}+0.11 x_{2}+0.38 x_{3}+0.02 x_{4}$,

where $y$ is energy intensity of primary energy; $x_{1}$ - share of enterprises that carried out technological innovation, $\% ; x_{2}$ - concentration of production, \%; $x_{3}$ - share of investments, $\% ; x_{4}$ - depreciation of basic production assets, $\%$.
It should be noted that the increase in $y$ is a negative characteristic of the energy sector and corresponds to the unfavorable forecast.

The development of energy in Russia is a priority task of the state, as evidenced by the Energy Strategy of Russia developed and being implemented at the moment. Let us consider the key elements of the forecast for the development of the fuel and energy sector, as amended by the results of the regression analysis (Table 3 ).

According to the authors' forecast, the growth of the share of hydropower resources in the country's fuel and energy balance will take place for the following reasons: their stocks in the Eastern part of the country and growth of energy demand in the outer Eastern market are considerable.

The conducted regression analysis has confirmed theoretical assumptions about the favorable influence of innovation activity on the state of the fuel and energy sector. According to the results of the analysis, this factor contributes to a decrease in the level of energy intensity. 
Table 3. Key directions for the development of the fuel and energy complex of Russia

Source: Key World Energy Statistics (2016), The Global Innovation Index (2016).

\begin{tabular}{|c|c|c|}
\hline Indicators & $\begin{array}{l}\text { The Energy Strategy } \\
\text { of Russia till } 2035\end{array}$ & Authors' forecast \\
\hline Energy carriers & Oil, coal, natural gas, nuclear fuel & Oil, natural gas, nuclear fuel, hydroenergy resources \\
\hline Markets & $\begin{array}{l}\text { reduction of European markets; } \\
\text { expansion of markets of the Asia- } \\
\text { Pacific region; } \\
\text { decrease in export of oil products; } \\
\text { development of domestic markets }\end{array}$ & $\begin{array}{l}\text { increase in volumes of deliveries to Asian countries; } \\
\text { decrease in volumes of deliveries to European countries; } \\
\text { liberalization of domestic markets; } \\
\text { reduction of specific weight of export of oil products; } \\
\text { export growth of oil products will be promoted by investments } \\
\text { into branch fixed }\end{array}$ \\
\hline $\begin{array}{l}\text { Price of energy } \\
\text { resources }\end{array}$ & $\begin{array}{l}\text { Increase in prices for oil to } 80-95 \\
\text { dollars a barrel }\end{array}$ & $\begin{array}{l}\text { Increase in prices for energy carriers in connection with the } \\
\text { development of power-intensive industries. Increase in prices } \\
\text { will remain approximate till } 2040 \text { - a peak of the economic } \\
\text { development of the sixth technological wave }\end{array}$ \\
\hline Consumption & $\begin{array}{l}\text { Increase in consumption of primary } \\
\text { energy by } 17 \%\end{array}$ & $\begin{array}{l}\text { Growth in consumption of energy resources by the branches } \\
\text { of a new technological wave }\end{array}$ \\
\hline Innovation & $\begin{array}{l}\text { management and regulation of } \\
\text { markets; } \\
\text { mining, processing and transportation } \\
\text { technologies; } \\
\text { state support programs of innovation } \\
\text { activity; } \\
\text { closed model of innovation process }\end{array}$ & $\begin{array}{l}\text { automation of mechanisms of market interaction by means of } \\
\text { electronic trading platforms; } \\
\text { mining, processing, generation technologies and technologies } \\
\text { of transportation of energy resources; } \\
\text { approaches and instruments of enterprises management; } \\
\text { open model of innovation process }\end{array}$ \\
\hline $\begin{array}{l}\text { Energy intensity of } \\
\text { GDP }\end{array}$ & $\begin{array}{l}\text { Decrease in energy intensity of GDP } \\
\text { by } 1.6 \text { times }\end{array}$ & $\begin{array}{l}\text { It is possible to achieve the planned reduction in the energy } \\
\text { intensity of GDP only if innovation activity of enterprises is } \\
\text { increased by more than } 1000 \text { times. The amendment should } \\
\text { be made: the analysis took into account only innovation } \\
\text { activity of energy companies, but not all economic activities. } \\
\text { In addition, there may be other factors that reduce energy } \\
\text { intensity, which have not been taken into account in the } \\
\text { simulation }\end{array}$ \\
\hline
\end{tabular}

Note: Numerical indicators in the authors' forecast are the result of the regression and correlation analysis.

As a result of the analysis, it has been revealed that the energy intensity reduction planned in the Energy Strategy will require a significant increase in innovation activity of both the fuel and energy complex and the entire national economy.

The scientific literature, including where forecasting is considered, traditionally indicates that depreciation of basic production assets in the fuel and energy complex negatively affects energy intensity, but in comparison with other factors its influence is insignificant. At the same time, the increase in the capital intensity of the complex's branches leads to the significant increase in energy intensity of the economy. However, more attention should be paid not to the volume, but to the structure of investments, they should ensure, first of all, the development of innovation activities.

The expected results are the results of the regression analysis with respect to the "concentration of production" factor - the withdrawal of branch market structures from a perfect condition has a negative impact on innovation activity on which energy intensity depends.
Thus, the conducted regression analysis confirms the theoretical propositions formulated by the authors of the article on forecasting the development of the fuel and energy complex of Russia:

3. The condition and development of the fuel and energy complex is influenced by such factors as "the state of the complex's industrial markets" and "technical and economic problems of the complex". These factors are quantitative, their projected values can be estimated on the basis of available information and, most importantly, they are manageable. These factors should be taken into account in the process of making a forecast for the development of the fuel and energy complex of Russia in the first place.

4. The state of the fuel and energy complex of Russia is largely determined by innovation. Therefore, when predicting the development of the domestic fuel and energy complex in the factor of "technical and economic problems of the complex", it is necessary to take into account such indicators as "innovation activity", "level of innovation infrastructure development", "costs for innovation". 


\section{DISCUSSION}

The development forecasts for FEC, provided by the researches from the literary review, are limited by foreign policy and economic factors. They reduce their relevance in the context of the intensive development of science and technology, and their considerable influence on economics. The fuel and energy complex represents the set of technically challenging production and service processes, the efficiency of which is a subject of research and development. Besides, efficiency of all other branches of the national economy depends on the level of the technical development and equipment of the FEC. One of the key problems and the top-priority goal for researchers is GDP energy intensity of Russia. That is why it is necessary to consider current changes in science and technology on a worldwide scale and innovative activity in the complex while drawing up the development forecast for the native FEC.

The forecast, developed by the authors, considers not only the external economic factors, but also the dynamics of technological waves, innovative activity of enterprises of the complex, and also the Energy Strategy of Russia until 2035.

The regression model obtained in the course of the study can be improved by reducing the degree of multicollinear factors by means of their more precise formulation and structuring. In particular, this concerns the factor reflecting investments in the fuel and energy sector.

\section{CONCLUSION}

The study carried out by the authors made it possible to identify and quantify factors affecting the development of the fuel and energy complex of Russia. The developed regression model allows predicting the state of the complex for different values of these factors. The positive impact of innovation on the development of the domestic fuel and energy complex was proved, as well as the fact that the scale of this activity should be very significant in order to achieve those indicators that have been planned in the Energy Strategy of Russia.

The existing technical and economic and organizational problems of the Russian FEC are the target for scientific research and state reforms. Its rapid and effective elimination is possible only as a result of the development of the FEC energy industry of innovative activity. The changing conditions of economic management at the world and national levels act as an external incentive to enhance innovation activity of the complex's enterprises. Therefore the development of the Russian FEC in the next 20 years (time of the formation and development of the VI technological wave) is defined by the development of science and technology. The increase in innovation activity both in the complex, and in other branches of the national economy will lead to changes in the structure of energy consumption and, as a result, to energy intensity of GDP.

\section{REFERENCES}

1. Bildirici, Melike. (2016). Defense, Economic Growth and Energy Consumption in China. Procedia Economics and Finance, 38, 257263.

2. Bushuev, V. V. (2014). Jenergija $i$ sud'ba Rossii. M.: Jenergija, 292 s.

3. Bushuev, V. V., Gromov, A. I., Kurichev, N. K., Nikolaev, M. A., Solov'ev, D. A., Timatkov, V. V.,
\& Chernikov, A. A. (2012). Jenergeticheskie istoki i posledstvija global'nogo krizisa 2010-h godov. Monografija. Moscow: Jenergija, $88 \mathrm{~s}$.

4. Demina, O. V., \& Novickij, A. A. (2012). Jenergeticheskie rynki stran ATJeS: vozmozhnosti dlja Rossii. Prostranstvennaja Jekonomika, 3, 55-78.
5. Dirk, Jan van de Ven, \& Roger, Fouquet. (2017). Historical energy price shocks and their changing effects on the economy. Energy Economics, 62, 204-216.

6. Doklad i prezentacija $\mathrm{k}$ vystuplenju zamestitelja Ministra Alekseja Tekslera na forume TJeK Rossii v XXI veke. (2014). Oficial'nyj sajt Ministerstva 
jenergetiki $R F$. Retrieved from http://www.minenergo.gov.ru/ press/doklady/18298.html (accessed on 17.01.2015).

7. Federal'nyj bjudzhet. Oficial'nyj sajt Ministerstva finansov RF. Retrieved from http://minfin.rf/ $\mathrm{ru} /$ perfomance/budget/federal budget/budgeti/11-16/ (accessed on 13.02.2017).

8. Galkina, A. A., Grushevenko, E. V., Grushevenko, D. A., Kulagin, V. A., \& Sorokin, S. N. (2011). Prognoz do 2040 goda. Glavnye problemy i vyzovy dlja jenergetiki. Nezavisimaja gazeta. Retrieved from http://www.ng.ru/ng_energiya/2013-06-11/11_prognoz.html (accessed on 09.11.2014).

9. Glaz'ev, S. Ju. (2007). Strategija operezhajushhego razvitija rossijskoj jekonomiki v uslovijah global'nyh tehnologicheskih sdvigov. M.: NIR, 134 s.

10. Glazev, S. Ju. (2010). Strategija operezhajushhego razvitija rossijskoj jekonomiki v uslovijah global'nogo krizisa. M.: Jekonomika, 287 c.

11. Glazev, S. Ju., \& Kharitonov, V. V. (2009). Nanotehnologii kak kljuchevoj faktor novogo tehnologicheskogo uklada $v$ jekonomike. M.: Trovant, $304 \mathrm{~s}$.

12. Godovaja otchetnost' Goskorporacii "Rosatom". Oficial'nyj sajt Goskorporacii “Rosatom”. Retrieved from http://www.rosatom.ru/about/ publichnaya-otchetnost/ (accessed on 11.02.2017).

13. Gorshenin, V. (2010). Shestoj tehnologicheskij uklad: vyzovy dlja Rossii. Biznes-Kljuch, 3-4(40-41), 22-24.

14. Ispolnenie Federal'nogo bjudzheta. Oficial'nyj sajt Kaznachejstva Rossii. Retrieved from http:// datamarts.roskazna.ru/ (accessed on 11.02.2017).

15. Istorija rossijskoj jenergetiki. Oficial'nyj sajt Ministerstva jenergetiki RF. Retrieved from http://www. minenergo.gov.ru/aboutminen/ historical_calendar/ (accessed on 20.01.2016)

16. Ivanter, V. V., \& Panfilov, V. S. (2011). Konec jekonomiki rosta ili smena paradigmy razvitija? Vestnik Rossijskoj akademii nauk, 7, 594-600.
17. Key World Energy Statistics. (2016). The official website of International Energy Agency. Retrieved from http://www.iea.org/publications/freepublications/publication/ KeyWorld_Statistics_2015.pdf (accessed on 11.02.2017)

18. Kipnis, E. A. (2014). Tendencii razvitija mirovoj jenergetiki. Mezhdunarodnyj akademicheskij vestnik, 6(6), 60-62.

19. Lapaeva, M. G., \& Lapaeva, O. F. (2004). Osnovnye jetapy formirovanija i razvitija toplivnojenergeticheskogo kompleksa. Vestnik OGU, 8, 4-12.

20. Lin Zheng-Wei, Hsu Sam TingHsin, Huang Chin-Sheng. (2014) Technical analysis and market efficiency: an empirical examination on energy markets. Investment Management and Financial Innovations, 11(1), 189-199. Retrieved from https://businessperspectives. org/journals/investment-management-and-financial-innovations/ issue-1-cont-9/technical-analysisand-market-efficiency-an-empirical-examination-on-energymarkets

21. Makarov, A. A., Mitrova, T. A., \& Kulagin, V. A. (2012). Dolgosrochnyj prognoz razvitija jenergetiki mira i Rossii. Jekonomicheskij zhurnal Vysshej shkoly jekonomiki, 2, 172-203.

22. Maslennikova, Ju. A. (2010). Sovremennye problemy jekonomiki i upravlenija neftegazovym proizvodstvom. Trudy Rossijskogo gosudarstvennogo universiteta nefti i gaza im. I. M. Gubkina, 2, 144-151.

23. Mercure, Jean-Francois, \& Salas, Pablo (2013). On the global economic potentials and marginal costs of non-renewable resources and the price of energy commodities. Energy Policy, 63, 469-483.

24. Mirkin, Ja. M. (2014). Neftjanaja lovushka. Prjamye investicii, 4(144), 18-21.

25. Oficial'nyj sajt Vsemirnogo banka. Retrieved from http://data. worldbank.org/russian (accessed on 11.02.2017).
26. Ostrouhova, N. G. (2015a).

Obzor problem otechestvennogo toplivno-jenergeticheskogo kompleksa. Vestnik Tjumenskogo gosudarstvennogo universiteta. Social'no-jekonomicheskie i pravovye issledovanija, T. 1, 4(4), 138-148.

27. Ostrouhova, N. G. (2015b). Sovremennoe stojanie i kljuchevye tendencii razvitija mirovyh jenergeticheskih rynkov posledstvija dlja Rossii. Vestnik Novosibirskogo gosudarstvennogo universiteta. Serija: Social'nojekonomicheskie nauki, 15(2), 23-35.

28. Otchetnost' PAO "Gazpom". (2016). Oficial'nyj sajt PAO "Gazprom". Retrieved from http:// www.gazprom.ru/investors/ (accessed on 11.02.2017).

29. Otchetnost' PAO "RusGidro". Oficial'nyj sajt PAO "RusGidro". Retrieved from http://www. rushydro.ru/investors/reports/ (accessed on 11.02.2017).

30. Otchetnost', prezentacii, godovye otchety PAO "NK "Rosneft". Oficial'nyj satj PAO "NK "Rosneft". Retrieved from https://www.rosneft.ru/Investors/ statements_and_presentations/ Statements/ (accessed on 11.02.2017)

31. Plakitkin, Ju. A. (2012). Mirovoe razvitie i zakonomernosti global'noj jenergetiki. Vestnik rossijskoj akademii estestvennyh nauk, 3, 3-10.

32. Plakitkin, Ju. A. (2013). Ceny na neft' - perspektiva padenija vozmozhna. Vestnik rossijskoj akademii estestvennyh nauk, 1 , 52-57.

33. Postaliuk, Mikhail, \& Kwon, Gulnara. (2014). Evaluation of an innovative project of saving energy in housing and communal services. Investment Management and Financial Innovations, 11(1), 70-76. Rertrieved from https:// businessperspectives.org/journals/ investment-management-andfinancial-innovations/issue-96/ evaluation-of-an-innovative-project-of-saving-energy-in-housingand-communal-services 
34. Rossijskij statisticheskij ezhegodnik. Oficial'nyj sajt Federal'noj sluzhby gosudarstvennoj statistiki. Retrieved from http://www.gks.ru/ wps/wcm/connect/rosstat_main/ rosstat/ru/statistics/publications/ catalog/doc_1135087342078 (accessed on 11.02.2017).

35. Rybcev, V. V. (2011). Perehod k shestomu tehnologicheskomu ukladu kak mehanizm perehoda $\mathrm{k}$ innovacionnomu puti razvitija. Kreativnaja jekonomika, 4(52), 3-8. Retrieved from http://www. creativeconomy.ru/articles/3388/ (accessed on 29.01.2015).
36. The Global Innovation Index. (2016). Winning with Global Innovation. The Global Innovation Index. Retrieved from https://www. globalinnovationindex.org/ gii-2016-report (accessed on 22.12.2016)

37. Trifonov, Ju. V., \& Letjagina, L. N. (2010). Innovacionnaja napravlennost' razvitija rossijskoj jenergetiki. Vestnik Nizhegorodskogo universiteta im. N. I. Lobachevskogo, 3(1), 245-248.
38. Tsakalos, Ioannis, Samitas Aristeidis, \& Kinias, Ioannis. (2015). Volatility spillovers between energy market and international financial markets. Investment Management and Financial Innovations, 12(2), 136-149.

Retrieved from https://businessperspectives.org/journals/investment-management-and-financial-innovations/issue-2-cont-7/ volatility-spillovers-between-energy-market-and-internationalfinancial-markets 